\title{
Facies pattern of the middle Permian Barren Measures Formation, Jharia basin, India: The sedimentary response to basin tectonics
}

\author{
PRABIR DASGUPTA \\ Department of Geology, Presidency College, 86/1 College Street, Kolkata 700 073, India. \\ e-mail: pdggeopc@cal3.vsnl.net.in
}

In the Lower Gondwana succession of the Jharia basin of eastern India, the Barren Measures Formation is characterized by the cyclic disposition of fine-grained lacustrine deposits and relatively coarse-grained fluvial deposits. The cyclic variation in the rate of coarse clastic input is attributed to the sedimentary response to basin tectonics. The sandstone-shale alternations of the Barren Measures succession can be correlated with the tectonic cyclothems developed on the hangingwall dip-slope and adjoining trough in a continental half-graben setting. Enhancement of the gradient of the hangingwall dip-slope during reactivation of the basin margin faults led to progradation of the existing fluvial system towards the half-graben trough and deposition of the coarser clastics on the fine-grained lacustrine deposits of the trough. Peneplanation of the hangingwall slope and slow increase in the lake level caused lacustrine transgression and retrogration of the fluvial system on the hangingwall block. The fluvial sediments were onlapped by the fine-grained lacustrine deposits. Episodic rejuvenation of the basin margin faults thus caused development of tectonic cyclothem on the hangingwall block. The paleocurrent pattern indicates that a persistent northward paleoslope was maintained during Barren Measures sedimentation. The inferred depositional settings were much more extensive than the present limit of the outcrop. The faults, presently defining the northern limit of the Barren Measures Formation, were possibly emplaced after Barren Measures sedimentation. The final movement along these fault planes caused preservation of the downthrown hangingwall block and the Barren Measures sediments on the footwall block were eroded during subsequent denudation. The Southern Boundary Fault came into existence after the deposition of the Barren Measures sediments.

\section{Introduction}

The role of basin tectonics in influencing sedimentation processes has long been recognized in sedimentological literature (Alexander and Leeder 1987; Leeder and Gawthorpe 1987). Basin tectonics results in recognisable imprints in the architecture of the basin-fills, and recognition of these signatures leads to reconstruction of the tectonosedimentary history of the basin. The Barren Measures Formation (middle Permian) of the Lower Gondwana succession of the Jharia basin, India, displays a complex arrangement of a large variety of siliciclastic facies associations related to variations in the depositional milieu. The present study aims at an appraisal of the role of basin tectonics on the disposition of distinctive facies associations and the reconstruction of tectono-sedimentary evolution of the basin.

\section{Geological setting}

The Jharia basin, a part of the east-west aligned Damodar-Koel group of Gondwana basins of India, lies between latitudes $23^{\circ} 37^{\prime} \mathrm{N}$ and $23^{\circ} 52^{\prime} \mathrm{N}$ and

Keywords. Jharia basin; Lower Gondwana; Barren Measures Formation; facies pattern; basin tectonics. 


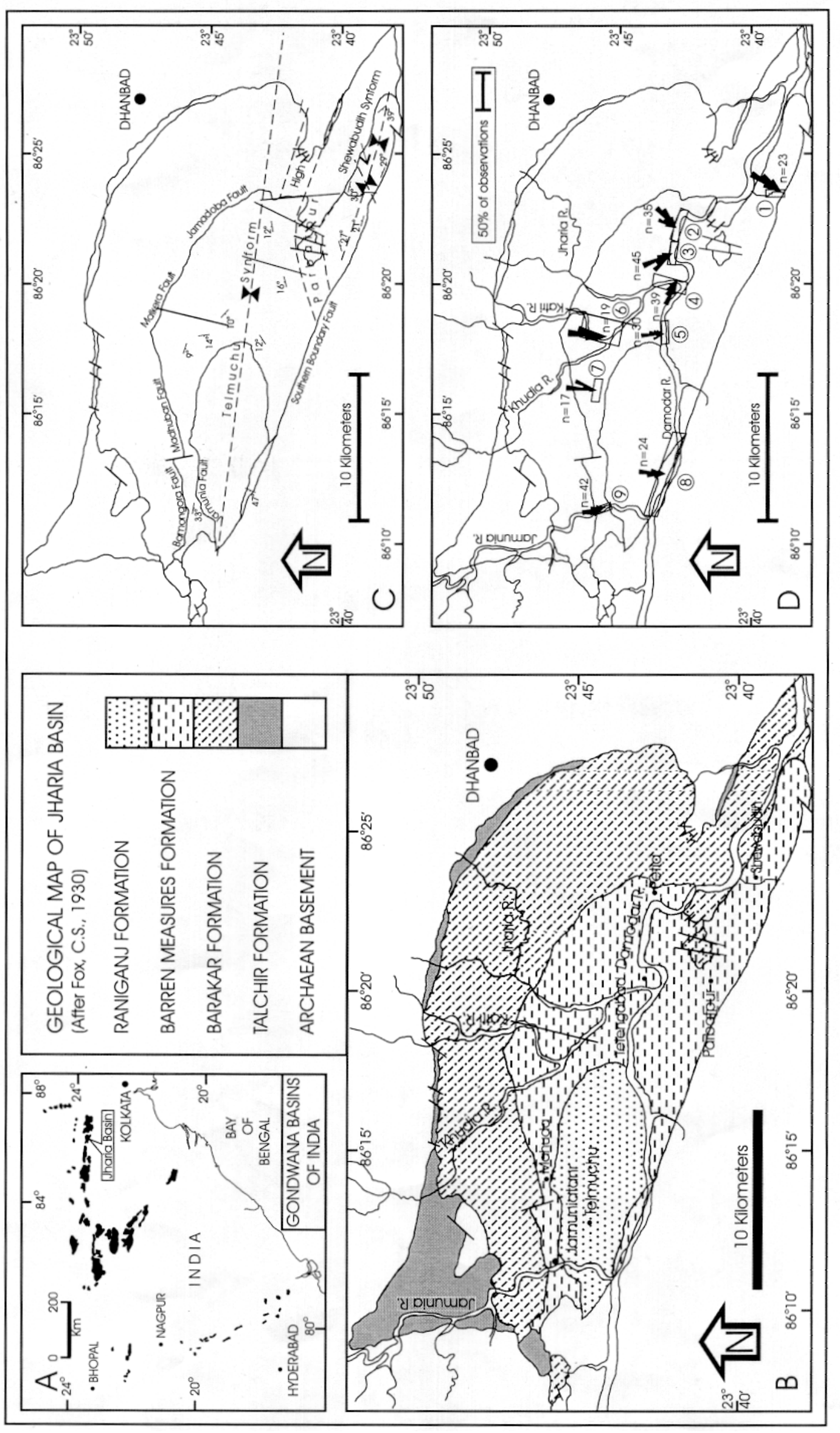

요요

㝴㱐

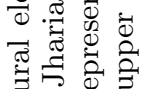

웜

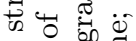

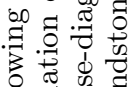

क

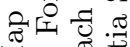

$\sum$ o

OU

를

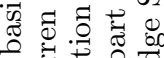

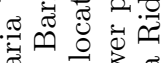

త్తై

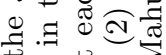

च

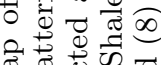

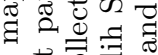

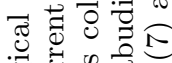

品

U 西, 讨

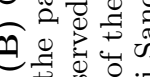

बำ

弪

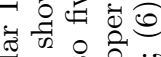

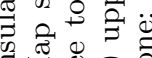

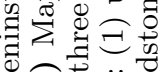

包如

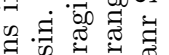

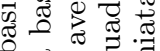

๘

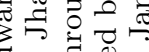

풩

ن

풍

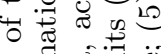

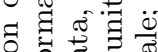

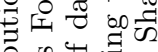

을

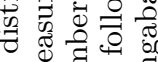

航

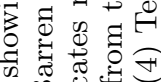

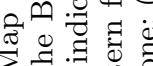

要焉

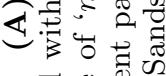

$\rightarrow$ 苾焉

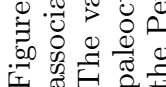


Table 1. Stratigraphic subdivisions of the Barren Measures Formation, Jharia basin, India.

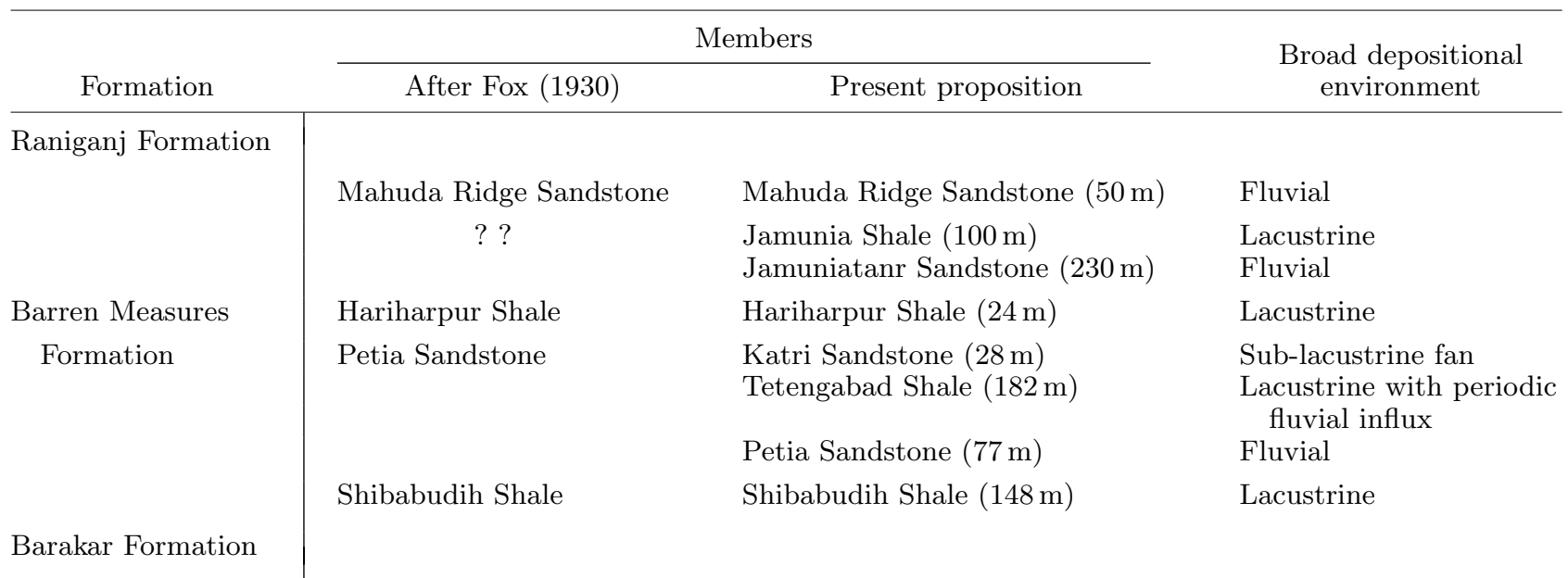

longitudes $86^{\circ} 5^{\prime} \mathrm{E}$ and $86^{\circ} 30^{\prime} \mathrm{E}$ (figures $1 \mathrm{~A}, \mathrm{~B}$ ). About $3000 \mathrm{~m}$ thick successions of Lower Gondwana (Permian) rocks, preserved within this basin, outcrops over an area of about $465 \mathrm{~km}^{2}$. The sedimentary succession, unconformably overlying the Archean gneissic basement, starts with the glaciogenic sediments of the Talchir Formation followed upward by fluvial and fluvio-lacustrine sediments successively of the Barakar, Barren Measures and Raniganj Formations (Fox 1930; Mehta and Murthy 1957; Sengupta et al 1979) (figure 1B), deposited within an intracratonic extensional setting (Ghosh and Mukhopadhyay 1985).

The Barren Measures Formation, approximately $750 \mathrm{~m}$ thick, outcrops in the central part of the basin and its northern and eastern boundaries are defined by a number of regional faults against the Barakar Formation (figure 1C) (Fox 1930; Ghosh and Mukhopadhyay 1985). The conformable relationship between the two is seen only in the southeastern part of the basin. Towards the south, the Barren Measures Formation abuts against the Archean basement along the Southern Boundary Fault (figure 1B). In the western part, the Raniganj Formation conformably overlies the Barren Measures Formation. The northern boundary of the elliptic outcrop the Raniganj Formation is, however, marked by the Jamunia Fault (figure 1C). The structural style of the Barren Measures rocks defines two broad regional folds, the doubly plunging Shewabudih Synform and the Telmuchu Synform, separated by an east-west trending regional horst (Parbatpur High) (figure 1C).

\section{Stratigraphic and depositional framework}

Fox (1930) pointed out that the Barren Measures Formation is characterized by alternate appearance of shale- and sandstone-dominated units, and recognized four members of the Barren Measures Formation (table 1). Sengupta et al (1979) and Mukhopadhyay (1984) considered the shaledominated members as lacustrine deposits and the sandstone-dominated ones as of fluvial origin, and suggested that advancing fluvial systems periodically interrupted the lacustrine condition. The present study reveals that based on distinctive lithological attributes, the Barren Measures succession can be subdivided into eight distinct units, and a 'member' status can be assigned to each of them (table 1). The lacustrine origin of the shale-dominated members, as inferred by the earlier workers (Sengupta et al 1979; Mukhopadhyay 1984), is indicated by the following:

- The shale-dominated members alternate with sandstone-dominated members of fluvial origin. Even the thickest shale-dominated member, the Tetengabad Shale, bears the signature of frequent fluvial influx. Rapid fluvial-offshore facies changes are suggestive of lacustrine environment (Picard and High 1972).

- In general, very low fossil content (as compared to the Barakar and the Raniganj Formations) characterises the Barren Measures Formation. The shale-dominated members, at places, record excellent preservation of some plant fossils, of which Vertebraria and Glossopteris are the most common varieties. Preservation of flattened, whole leaves in the Shibabudih Shale and the Jamunia Shale suggests quiet water deposition (Picard and High 1972). Profuse development of Vertebraria, in particular, suggests deposition in continental setting.

\subsection{Shibabudih Shale}

In the southeastern part of the basin, to the south of the Parbatpur High, the Barren Measures 


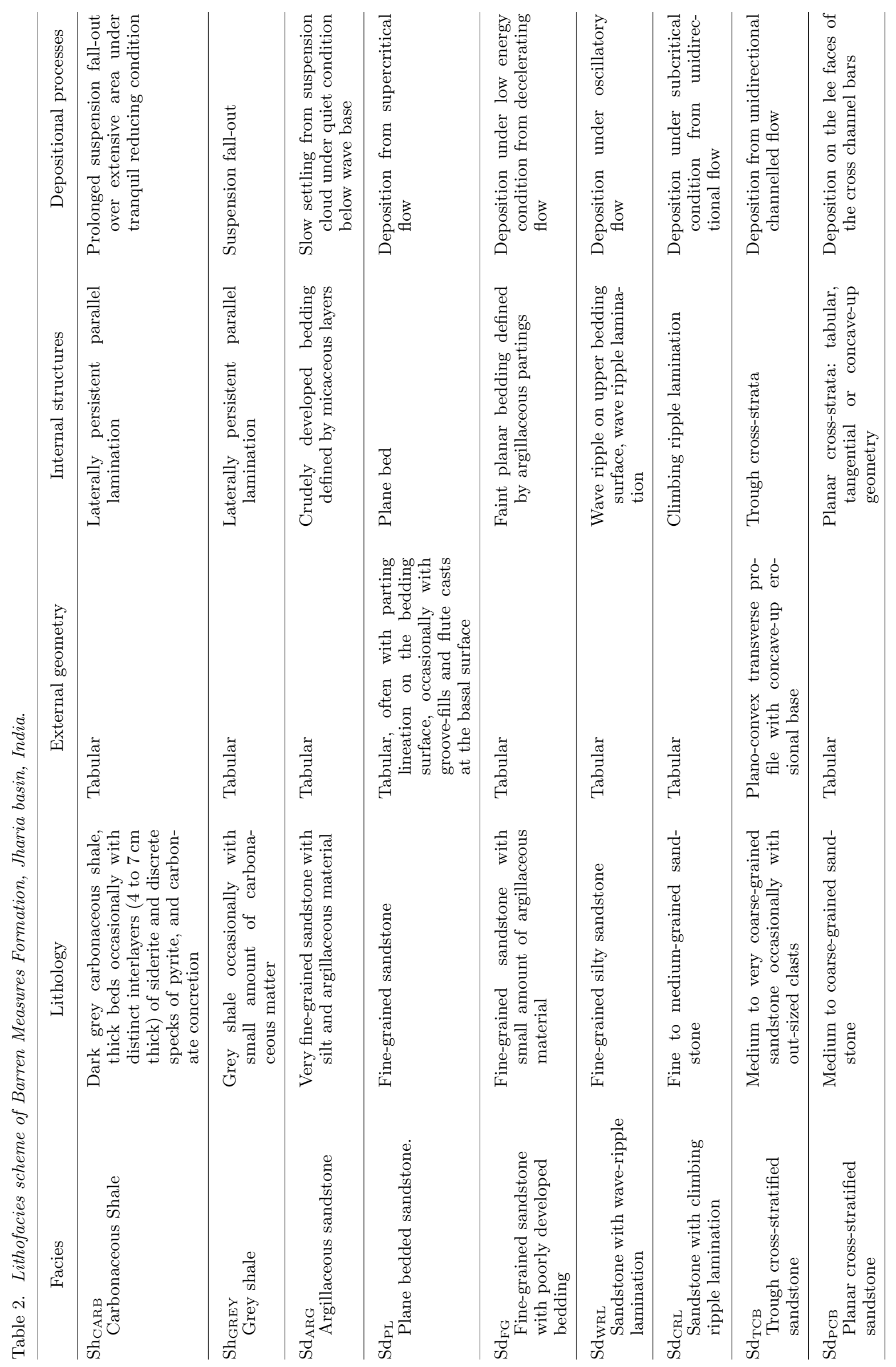




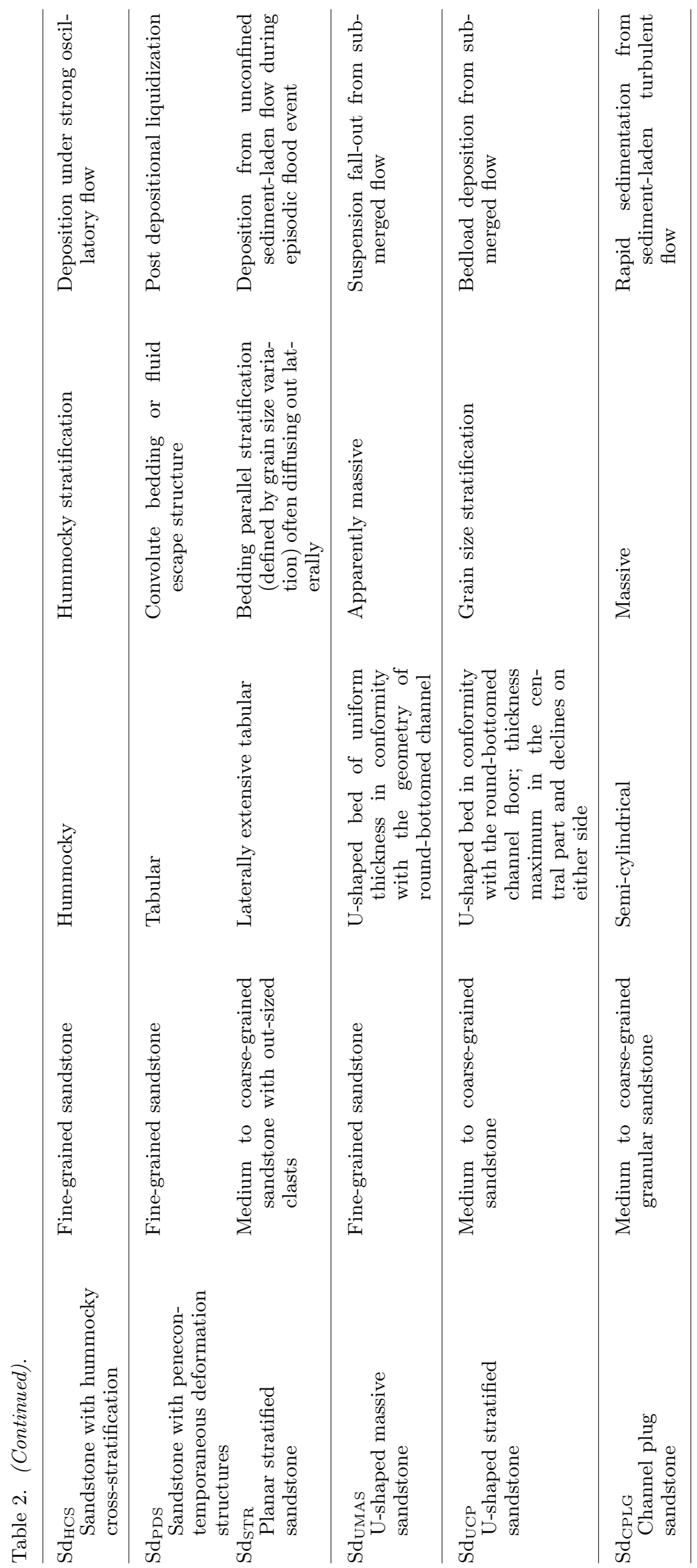


Formation is solely represented by the Shibabudih Shale (148 m thick). This member is best exposed along Shibabudih (local pronunciation - Shewabudih) Stream (figure 2) and overlies the braidplain deposits of the Barakar Formation (Casshyap 1979) exposed along the Damodar River. The contact between them is not exposed due to thick soil cover, though the attitudes of the bedding planes suggest a conformable relationship.

Alternate appearance of carbonaceous shale $\left(\mathrm{Sh}_{\mathrm{CARB}}\right)$ and argillaceous sandstone $\left(\mathrm{Sd}_{\mathrm{ARG}}\right)$ characterise the lower part $(122 \mathrm{~m})$ of the Shibabudih Shale with the local presence of wave-rippled sandstone $\left(\mathrm{Sd}_{\mathrm{WRL}}\right)$. The dark grey carbonaceous shale occurs as 6.5 to $24 \mathrm{~m}$ thick, laterally extensive tabular bodies with sharply defined confining surfaces. Impressions of Glossopteris are found within these carbonaceous shales. The shale often contains distinct layers (4 to $7 \mathrm{~cm}$ thick) of siderite and specks of pyrite.

The argillaceous sandstone $\left(\mathrm{Sd}_{\mathrm{ARG}}\right)$ (0.8 to about $9 \mathrm{~m}$ thick) units have sharp contact with the underlying carbonaceous shale. The sandstones are crudely bedded (bed thickness varies between 7 and $15 \mathrm{~cm}$ ), defined by laterally impersistent micaceous partings or thin argillaceous layers. This sandstone $\left(\mathrm{Sd}_{\mathrm{ARG}}\right)$ occasionally grades upward into the waverippled fine-grained sandstone $\left(\mathrm{Sd}_{\mathrm{WRL}}\right)$. The thickness of $\mathrm{Sd}_{\mathrm{WRL}}$ facies varies from 0.7 to $1.2 \mathrm{~m}$. Ripple profiles are either round or chevron type.

In the upper part $(36 \mathrm{~m})$ of the Shibabudih Shale, a few isolated channel-fills of trough crossbedded medium to coarse- grained sandstone $\left(\mathrm{Sd}_{\mathrm{TCB}}\right)$ (about 2 to $2.5 \mathrm{~m}$ thick) occur within relatively fine-grained argillaceous sandstone $\left(\mathrm{Sd}_{\mathrm{ARG}}\right)$. The width of these sandstone bodies rarely exceeds $40 \mathrm{~m}$. The facies is characterized by cosets (average set thickness $0.2 \mathrm{~m}$ ) of trough cross-beds without any internal second order surface.

Laterally extensive tabular geometry of shale with persistent lamination indicates suspension fall-out over an extensive area under tranquil conditions. High content of organic matter and occurrence of pyrite and siderite are suggestive of an overall anoxic condition. Talbot and Kelts (1990) have demonstrated that formation of siderite through bacterial decomposition of organic matter is an important diagenetic process in organic-rich lacustrine mud.

The lateral extent and great thickness of the argillaceous sandstone units suggest deposition from sediment-laden flows with very high concentration of sediments. Paucity of bedding planes might have been caused due to quick sedimentation from high-density viscous flows. Occurrence of micaceous partings and thin argillaceous layers, on the other hand, indicate emplacement of successive non-turbulent flows. Hence deposition of the argillaceous sandstone can be attributed to periodic influx of mass flow. The waverippled sandstone $\left(\mathrm{Sd}_{\mathrm{WRL}}\right)$ indicates deposition above the fair-weather wave base under continuous oscillatory flow.

The lower part of this member indicates that an overall reducing environment prevailed in this part of the basin over a long period, and sedimentation took place under quiet condition in a sub-basin separated from the main basin by the Parbatpur High (cf. Ghosh and Mukhopadhyay 1985). The tranquility was periodically interrupted by the influx of sediment-laden flows. The wave-rippled sandstones above argillaceous sandstone units point to the episodic shallowing of the sub-basin. During the late phase of deposition the loci of sedimentation of the Shibabudih Shale extended northward beyond the Parbatpur High. The presence of isolated channel-fills $\left(\mathrm{Sd}_{\mathrm{TCB}}\right)$ within argillaceous sandstone in the upper part of the Shibabudih Shale indicates occassional progradation of fluvial system due to shallowing of the basin.

\subsection{Petia Sandstone}

The Petia Sandstone conformably overlies the Shibabudih Shale, and occurs to the north of the Parbatpur High. Two distinct facies associations can be identified within the Petia Sandstone. The lower part (approximately $2.7 \mathrm{~m}$ thick) is represented by the facies association $\mathrm{FA}_{\mathrm{P} 1}$ (figure 2), which starts with a $0.8 \mathrm{~m}$ thick, laterally extensive, plane-bedded fine-grained sandstone $\left(\mathrm{Sd}_{\mathrm{PL}}\right)$ with profusely developed, elongate groove casts and flute casts at the base (figure 3 ). This facies is overlain by about $0.6 \mathrm{~m}$ thick, fine-grained sandstone with hummocky cross-stratification $\left(\mathrm{Sd}_{\mathrm{HCS}}\right)$ (figure 4). The hummocks are of varied dimension, and the wavelength varies between 0.8 and $1.9 \mathrm{~m}$. The $\mathrm{Sd}_{\mathrm{HCS}}$ is followed upward by $1.3 \mathrm{~m}$ thick laterally extensive tabular body of thinly bedded fine-grained argillaceous sandstone $\left(\mathrm{Sd}_{\mathrm{ARG}}\right)$. This association more or less conforms to the ideal HCS succession (Dott and Bourgeois 1982, 1983; Walker et al 1983; Martel and Gibling 1991) excepting the absence of wave-rippled interval.

The upper part (about $74 \mathrm{~m}$ ) of the Petia Sandstone is represented by the facies association $\mathrm{FA}_{\mathrm{P} 2}$. The trough cross-bedded sandstone $\left(\mathrm{Sd}_{\mathrm{TCB}}\right)$, plane-bedded fine-grained sandstone $\left(\mathrm{Sd}_{\mathrm{PL}}\right)$, argillaceous sandstone $\left(\mathrm{Sd}_{\mathrm{ARG}}\right)$, fine- to mediumgrained sandstone with climbing ripple lamination $\left(\mathrm{Sd}_{\mathrm{CRL}}\right)$ and grey shale $\left(\mathrm{Sh}_{\mathrm{GREY}}\right)$ are the main constituents of this association. The fine-grained sediments $\left(\mathrm{Sd}_{\mathrm{FG}}, \mathrm{Sd}_{\mathrm{ARG}}, \mathrm{Sd}_{\mathrm{CRL}}\right.$ and $\left.\mathrm{Sh}_{\mathrm{GREY}}\right)$ occur as laterally extensive tabular bodies (figure 5), and constitute a sub-association $\left(\mathrm{SA}_{\mathrm{P} 1}\right)$ with a distinct 


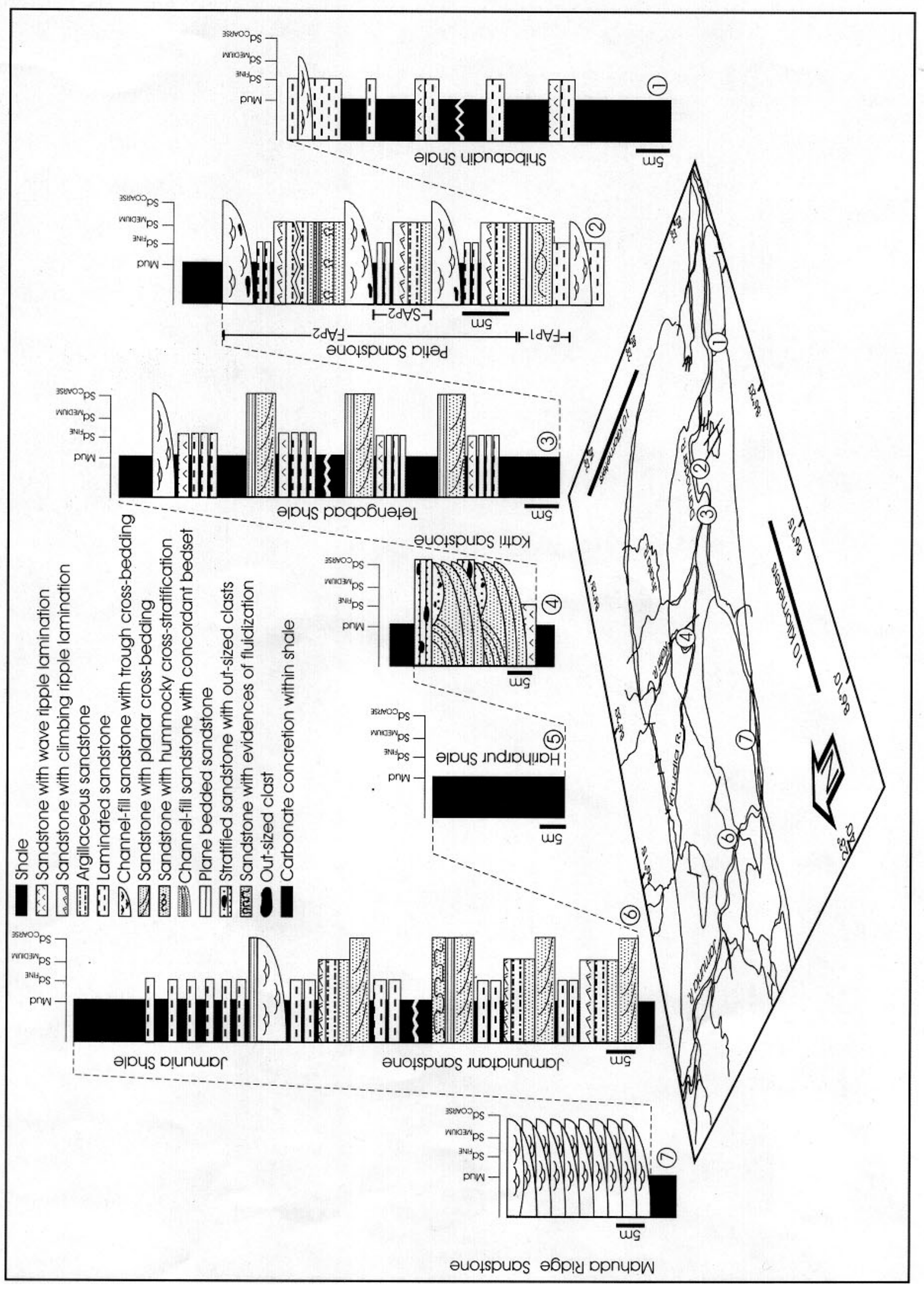

हี 


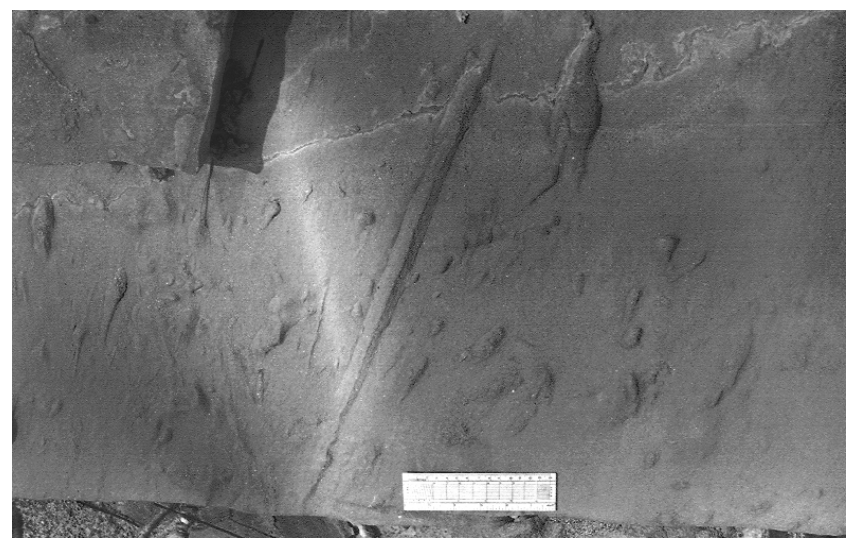

Figure 3. Groove-casts at the base of fine-grained sandstone beds of the Petia Sandstone, Damodar River Section (the scale is $15 \mathrm{~cm}$ long).

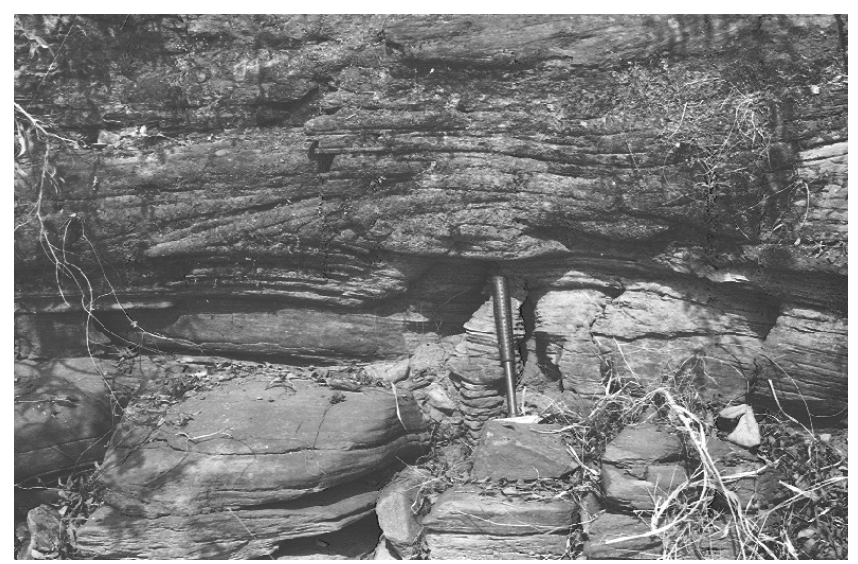

Figure 4. Hummocky cross-stratification showing thickening of laminae into the depression, Petia Sandstone, Damodar River Section (the hammer is $32 \mathrm{~cm} \mathrm{long).}$

fining-upward character (figure 2). The thickness of this sub-association normally varies between 2.8 and $5 \mathrm{~m}$. The trough cross-bedded sandstone $\left(\mathrm{Sd}_{\mathrm{TCB}}\right)$ occurs as channel-fill sand bodies incised within the fine-grained sediments of $\mathrm{SA}_{\mathrm{P} 1}$ and is the sole member of the other sub-association $\mathrm{SA}_{\mathrm{P} 2}$. The average thickness of these channel-fill sandstone units varies from 1.2 to $2.7 \mathrm{~m}$, whereas the channel width lies between 55 and $80 \mathrm{~m}$. Absence of internal erosional surfaces characterises these channel-fills. Gravelly (up to $10 \mathrm{~cm}$ in diameter) lag deposit with rip-up shale clasts at the base of these channel-fills is very common. The overall architecture of this association $\left(\mathrm{FA}_{\mathrm{P} 2}\right)$ marked by tabular bodies of fine-grained sediments with incised channel-fills points to a channel-floodplain association. The successive channel-fills show a distinct tendency of gradual westward shifting. The disposition of these channel-fills further suggests lateral channel migration with very low rate of

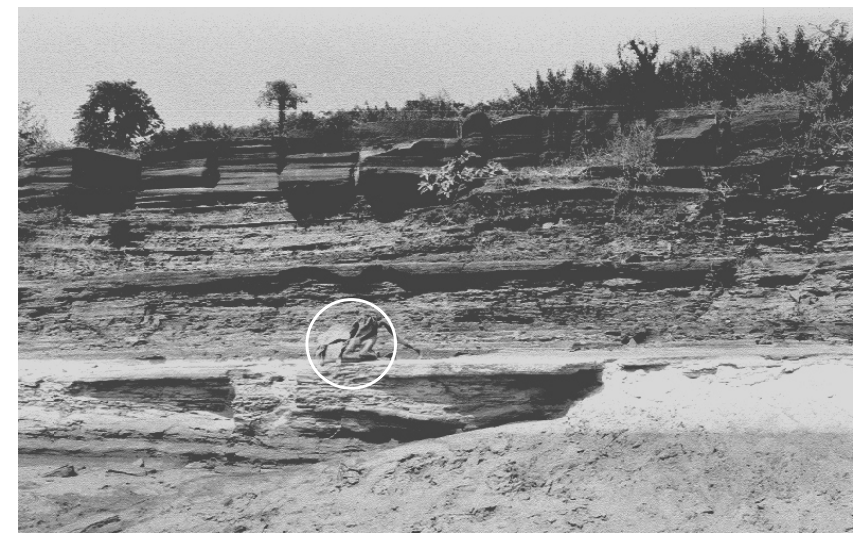

Figure 5. Typical floodplain deposit (sub-association $\mathrm{SA}_{\mathrm{P} 2}$ ) of the Petia Sandstone, Damodar River Section. Lateral persistence of the bedded units is noteworthy. The haversack (encircled) is for scale.

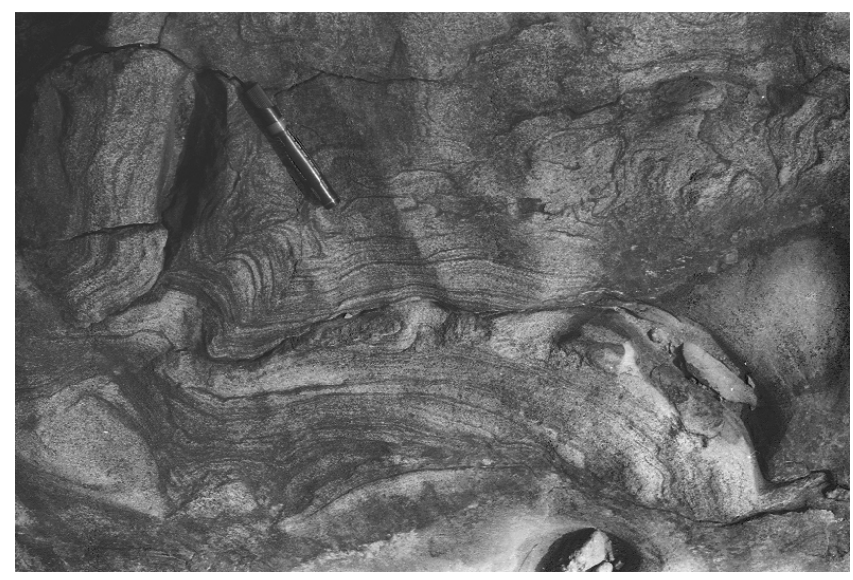

Figure 6. Part of a large fluid escape structure and associated contorted laminations in facies $\mathrm{Sd}_{\mathrm{PDS}}$ of the Petia Sandstone (the marker pen is $14.5 \mathrm{~cm}$ long), Damodar River Section.

contemporaneous subsidence (Miall 1985). Rotation of paleoflow direction towards the west has also been recorded within the channel-fills in the upper part of the succession (figure 1D). Besides the sub-associations described above, two beds of intensely fluidised fine-grained sandstone with large (about $2 \mathrm{~m}$ long) fluid escape structures $\left(\operatorname{Sd}_{\mathrm{PDS}}\right)$ (figure 6$)$ were encountered within Petia Sandstone succession. The fluidised sandstone layers are overlain by plane-bedded fine-grained sandstone with parting lineation $\left(\mathrm{Sd}_{\mathrm{PL}}\right)$ (occasionally with current crescents).

Hummocky cross-stratification indicates deposition by storm-generated waves (Harms et al 1975; Dott and Bourgeois 1982, 1983; Duke 1985, 1987). Experimental studies by Southard et al (1990) reveal that hummocky cross-stratification can be generated during sediment fallout from 


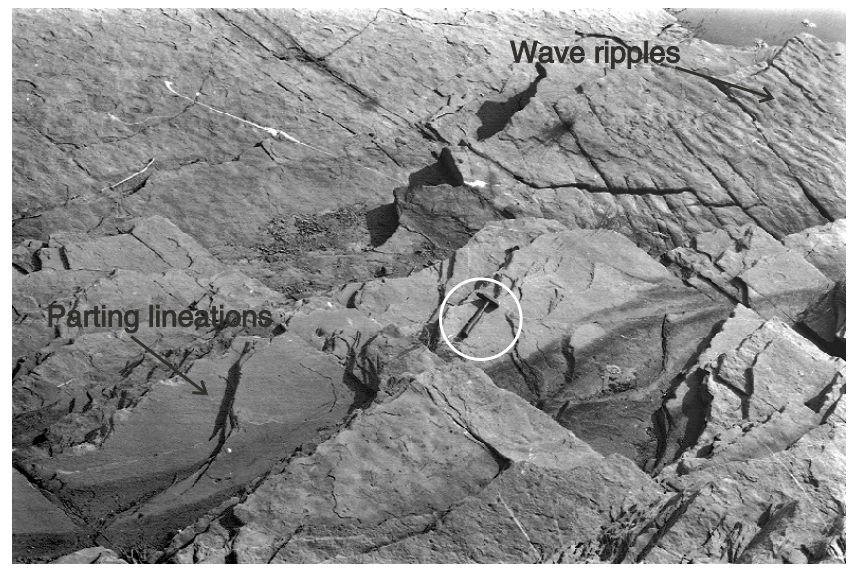

Figure 7. Photograph showing interbedded wave-rippled sandstone $\left(\mathrm{Sd}_{\mathrm{WRL}}\right)$ and plane-bedded sandstone with parting lineation $\left(\mathrm{Sd}_{\mathrm{PL}}\right)$ of the Tetengabad Shale, Katri River Section (the hammer is $32 \mathrm{~cm}$ long).

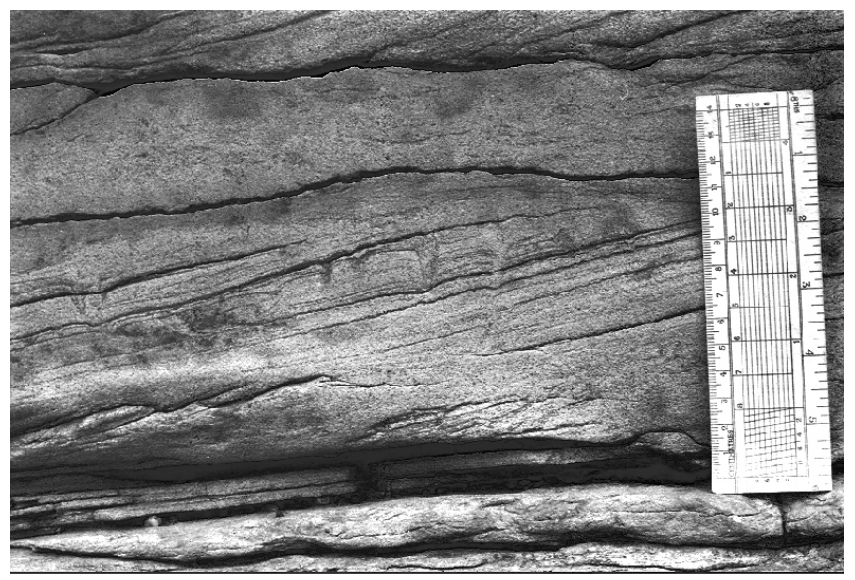

Figure 8. Planar cross-bedded sandstone $\left(\mathrm{Sd}_{\mathrm{PCB}}\right)$ with borings from the Tetengabad Shale. Tabular to tangential character of the foresets is apparent, Katri River Section.

strong purely oscillatory flows at moderate-to-long oscillation periods. According to Walker (1984), hummocky cross-stratification is best preserved below fair-weather wave base, but Duke (1985, 1987) pointed out that the lacustrine hummocky cross-stratification, generated by minor storms, may also be preserved in very shallow water. Martel and Gibling (1991) described hummocky cross-stratification from lacustrine deposits of Horton Bluff Formation of Canada. Greenwood and Sherman (1986) reported the HCS from the surf zone of Lake Huron. The nature of groove-fills, found at the base of fine-grained sandstone, closely resembles those commonly found within tempestite deposits (Myrow and Southard 1996). The overlying thinly bedded argillaceous sandstone $\left(\mathrm{Sd}_{\mathrm{ARG}}\right)$ indicates rapid deposition from suspension cloud following the recession of high energy wave action at current velocities below those required for the genesis of ripples (Reineck and Singh 1972; Martel and Gibling 1991). This type of suspension clouds can be generated by shoaling waves (Reineck and Singh 1972; Clarke et al 1982). In the present succession, a radical change in the depositional setting, immediately after the appearance of hummocky cross-stratification, is well documented. The facies association $\mathrm{FA}_{\mathrm{P} 1}$, in conjunction with the underlying succession of Shibabudih Shale, indicates an overall shallow lacustrine setting, while the facies mosaic of remaining part of the Petia Sandstone (facies association $\mathrm{FA}_{\mathrm{P} 2}$ ) suggests emplacement of fluvial setting in this part of the basin. Hence, an event of lacustrine regression, possibly in response to reactivation of the basin margin faults in the north, can be inferred. Intermediate phases of tectonic reactivation during deposition of the Petia Sandstone are indicated by the appearance of fluidised sandstone layers. Probably the riverine flows became incompatible with the channel system due to enhancement of slope during tectonic reactivation and unconfined flows came into existence. The appearance of planebedded sandstone with parting lineation above the fluidised sediments thus suggests the prevalence of supercritical unconfined flow following the episode of fluidisation. The trend of paleoflow indicated by these parting lineations does not deviate much (well within $10^{\circ}$ ) from the flow direction of the associated channel-fills.

\subsection{Tetengabad Shale}

The Tetengabad Shale overlies the Petia Sandstone, and is characterised by a cyclic repetition of shale and sandstone, the former being the dominant constituent (figure 2). The cycle thickness gradually decreases upward. Each cycle starts with carbonaceous shale $\left(\mathrm{Sh}_{\mathrm{CARB}}\right)$ (thickness varies from 3 to $9 \mathrm{~m}$ ) grading upward into a heterolithic sequence of fine-grained wave-rippled sandstone $\left(\mathrm{Sd}_{\mathrm{WRL}}\right)$ interbedded with thin layers of grey shale $\left(\mathrm{Sh}_{\mathrm{GREY}}\right)$ or occasionally with plane-bedded finegrained sandstone with parting lineation $\left(\mathrm{Sd}_{\mathrm{PL}}\right)$ (thickness varies between 1 and $3 \mathrm{~cm}$ ) (figure 7). Trough cross-bedded, medium- to coarse-grained sandstone units $\left(\mathrm{Sd}_{\mathrm{TCB}}\right)$ are found incised within interbedded sandstone-shale. Slump folds commonly occur within silt rich shale $\left(\mathrm{Sh}_{\mathrm{GREY}}\right)$ below the cross-bedded sandstone beds (figure 9). The sand-dominated heterolithic units vary from $80 \mathrm{~cm}$ to $3.5 \mathrm{~m}$ in thickness, and are followed upward by medium-grained planar cross-bedded sandstone $\left(\mathrm{Sd}_{\mathrm{PCB}}\right)$. The sandstone units $\left(\mathrm{Sd}_{\mathrm{PCB}}\right)$ (figure 8$)$ are tabular in nature (40 to $80 \mathrm{~cm}$ thick), and are laterally traceable for a few tens of metres. A 


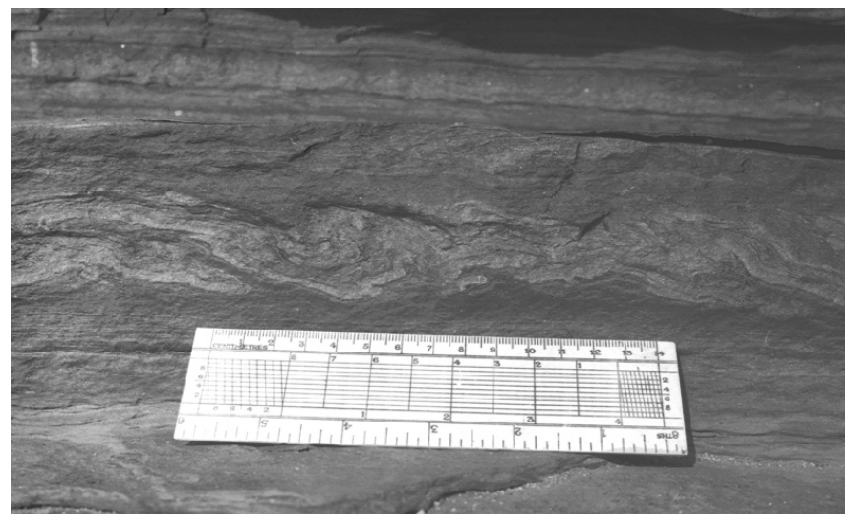

Figure 9. Slump structure within silt-rich grey shale of the Tetengabad Shale, Katri River Section.

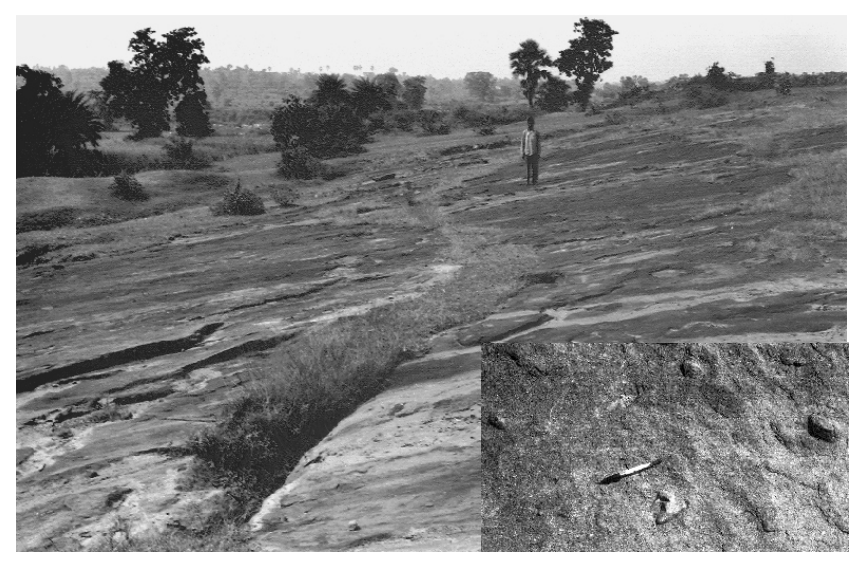

Figure 10. Exposure of the Katri Sandstone showing laterally extensive sheet-like sandstone apron with outsized clasts (inset), Katri River Section.

characteristic feature of this succession is the abundance of trace fossils within the upper part of each cycle. These are in the form of burrows, borings, negative and positive epirelief.

The carbonaceous shale $\left(\mathrm{Sh}_{\mathrm{CARB}}\right)$ implies that suspension fall-out under tranquil conditions prevailed for a long time. A high content of carbonaceous material indicates an overall anoxic condition in a lacustrine setting. Lacustrine regression is marked by the appearance of sanddominated heteroliths in the upper part of each cycle. Development of multiple cycles points to multiple events of retrogradation and progression. Emplacement of tabular units of trough crossbedded sandstones indicates progradation of fluvial system.

\subsection{Katri Sandstone}

Around the point of confluence of Katri and Khudia rivers (figures 1 and 3 ) a sandstone deposit, the Katri Sandstone, outcroping over an area of approximately $1.5 \mathrm{~km}^{2}$, appears as a lensoid body
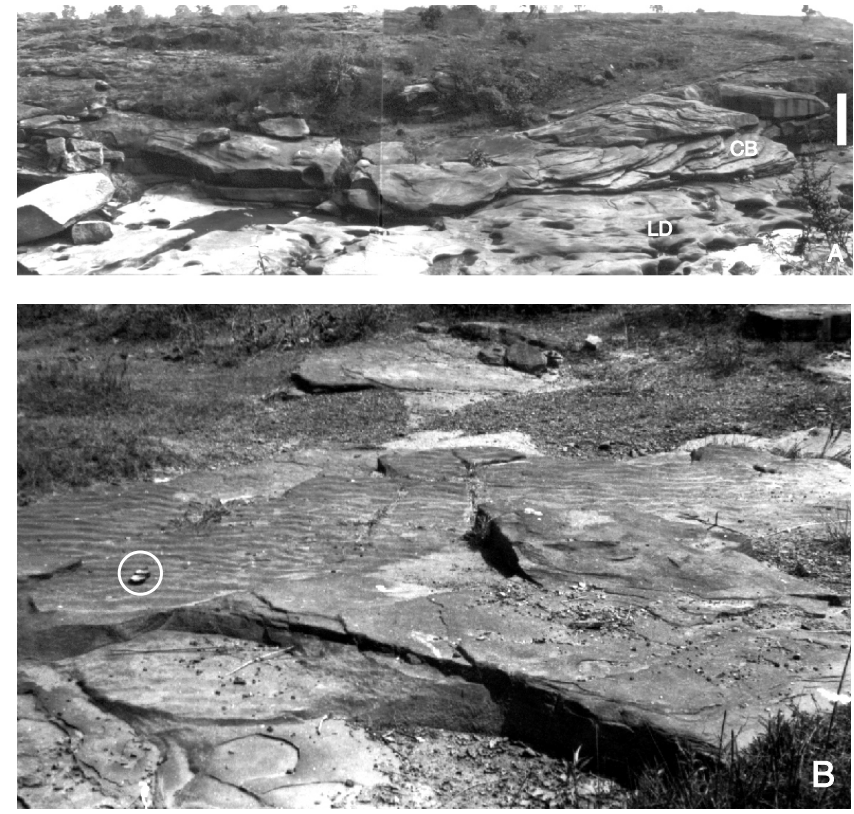

Figure 11. (A) Stacked channel-fills of the Katri Sandstone, Katri River Section. Distinct concordant bedset (CB) is seen in the lower right channel fill. Broad round- bottomed nature of the channel geometry is apparent. The whole stack is resting above the older lacustrine deposit (LD) exposed along the river bed. The white bar is $4 \mathrm{~m}$ long. (B) Tabular fine-grained sandstone of older lacustrine deposit with wave-rippled surface. The Brunton Compass (encircled) is for scale.

between the Tetengabad Shale and the overlying Hariharpur Shale.

The Katri Sandstone comprises laterally extensive, gently dipping sheet-like sandstone bodies with incised channel-fill deposits. The sheet sandstones $\left(\mathrm{Sd}_{\mathrm{STR}}\right)$ are planar stratified with bed thickness varying between 30 and $72 \mathrm{~cm}$ (figure 10). The sandstones are coarse-grained, poorly sorted and often contain small amounts of granules and pebbles and a few out-sized (largest one measures $17 \mathrm{~cm}$ in diametre) clasts.

The channel-fill sandstone deposits, incised within the sandstone sheets show a uniform broad round-bottomed geometry (figure 11A). The width/depth ratio, estimated from a few betterpreserved channels, varies approximately between 7 and 13.5. Two distinct bed geometries are identified within these channel-fills:

(1) concordant bedsets in approximate conformity with the round-bottomed geometry of the channel, and

(2) semicylindrical beds without internal stratification.

In the southeastern part, the Katri Sandstone is dominated by the sheet sandstone with a few channel plug deposits, and in the northwestern part, it shows alternate disposition of the stacked 


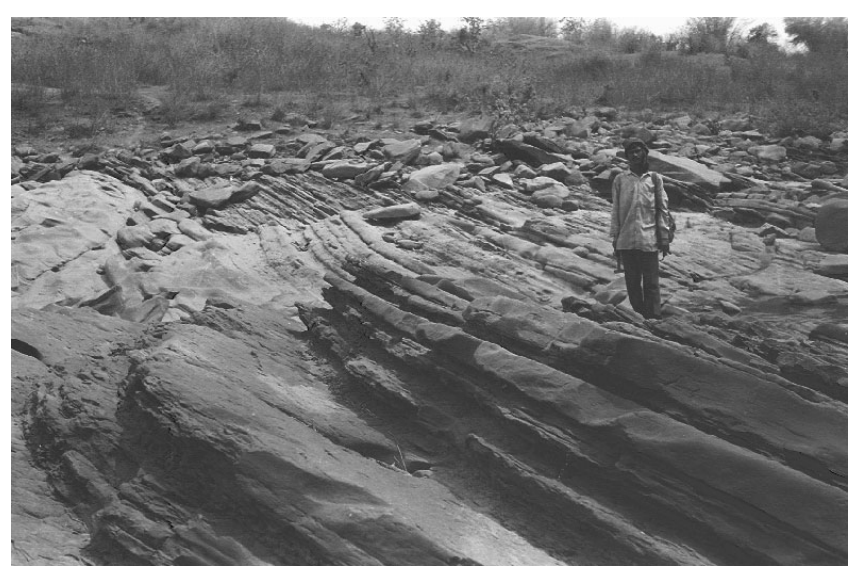

Figure 12. Photograph showing the laterally extensive bedded character of the Jamuniatanr Sandstone.

channel-fills and the sandstone sheets. The successive sandstone sheets, particularly those separated by stacked channel-fills, often display a poorly defined radial pattern of dip. In the Katri River section the channel-fill sandbodies curved down, with a marked fall in channel gradient and tangentially overlaid the relatively low-dipping wave-rippled sandstone of the Tetengabad Shale (figure 11B).

Laterally extensive sheets of coarse-grained sandstone showing planar stratification have been reported from many catastrophic sheet flood deposits, and attributed to deposition from swift, heavily sediment-laden turbulent flows (Harrison and Fritz 1982; Smith 1986; Smith and Lowe 1991). The presence of scattered out-sized clasts further suggests that the flow was competent to transport cobbles in suspension and attest to simultaneous deposition of sand and cobbles (Smith 1986).

Smooth round-bottomed geometry, in particular, suggests that the channels were completely filled in with fluid (Fisher 1977) and substantiates the subaqueous condition. The experimental observations by McKee (1957) suggest that these channels had been carved within unconsolidated cohesionless sediment by submerged turbulent flows, filled up by subsequent submerged flow or by suspension fallout. In either situation, the channel is concordantly filled but in the former case the strata thicken towards the bottom, and in the latter case the thickness remains the same. The semicylindrical massive channel-fills $\left(\mathrm{Sd}_{\mathrm{CPLG}}\right)$ are characterised by poorly sorted pebbly sandstone composed mainly of grains ranging between fine sand and coarse pebbles. The fillings are interpreted as channel plugs rapidly deposited from sediment-laden turbulent flow (Dasgupta 2002a).

Dasgupta (2002a) carried out a detailed facies analysis of the Katri Sandstone, and interpreted this deposit as a sublacustrine fan, and related it to an intrabasinal normal faulting of limited lateral extent. Accumulation of the clastic input within the associated hangingwall syncline led to the formation of the sublacustrine fan within a broad lacustrine setting.

\subsection{Hariharpur Shale}

The Hariharpur Shale is represented by laterally extensive carbonaceous shale $\left(\mathrm{Sh}_{\mathrm{CARB}}\right)$ overlying the Tetengabad Shale and the Katri Sandstone, and attains a maximum thickness of about $24 \mathrm{~m}$ in the type section, the Katri River section (figure 2). The shale is dark grey, evenly laminated, fissile and highly fragile, and contains a high amount of carbonaceous matter. In the Damodar River section impressions of Vertebraria are found preserved within this shale.

The presence of carbonaceous material, Vertebraria and laterally persistent lamination collectively suggest that the shale was deposited under tranquil, deep-water lacustrine condition.

\subsection{Jamuniatanr Sandstone}

The Jamuniatanr Sandstone, comprises a thick succession of very fine to medium-grained (occasionally coarse-grained) sandstone and shale, and conformably overlies the Hariharpur Shale in the Damodar River and Khudia River sections. In the Jamunia River section, the Jamuniatanr Sandstone is about $230 \mathrm{~m}$ thick, and is best exposed below the railway bridge near the Jamuniatanr Railway Station (figure 2).

The succession is characterised by cyclic repetition of fining-upward sequences showing an upward transition from medium to coarse-grained sandstone with planar cross-bedding $\left(\mathrm{Sd}_{\mathrm{PCB}}\right)$ through medium to fine-grained sandstone with climbing ripple laminations $\left(\mathrm{Sd}_{\mathrm{CRL}}\right)$, to laminated very finegrained silty sandstone $\left(\mathrm{Sd}_{\mathrm{FG}}\right)$-grey shale $\left(\mathrm{Sh}_{\mathrm{GREY}}\right)$ heterolithics. Medium to fine-grained sandstone with convolute bedding and fluid escape structure $\left(\mathrm{Sd}_{\mathrm{PDS}}\right)$ frequently appears within this succession. Laterally extensive tabular geometry characterises the constituent facies (figure 12). A few channelfills of trough cross-bedded sandstone $\left(\mathrm{Sd}_{\mathrm{TCB}}\right)$ occur within laminated silty sandstone-shale heterolithics.

Altogether 28 fining-upward cycles have been identified in the Jamunia River section. In the lower part of the succession the thickness of cycles ranges between 8 and $10 \mathrm{~m}$, in the middle part the average value is about $16 \mathrm{~m}$, and in the upper part the cycles tend to become thinner (about 2 to $6 \mathrm{~m}$ thick).

Dominance of planar-tabular cross-beds as well as tabular geometry of the sandstone beds at the 
basal part of the fining-upward sequence indicate deposition from low velocity flows within broad and shallow channels (Rust and Gibling 1990). The climbing ripple laminated beds indicate deposition from virtually unconfined, waning flood flows. The overall character indicates a distal braid-plain setting (Miall 1996). The thinly laminated silty sandstone $\left(\mathrm{Sd}_{\mathrm{FG}}\right)$, appears to be a product of suspension fall-out over a vast area. The channel-fills, within the laminated silty sandstone-grey shale, indicate occasional development of channelised flow.

\subsection{Jamunia Shale}

In the Jamunia River section, the Jamuniatanr Sandstone is conformably overlain by about $100 \mathrm{~m}$ thick dark grey shale $\left(\mathrm{Sh}_{\mathrm{CARB}}\right)$ rich in carbonaceous matter (figure 2). Large carbonate concretions (largest one measures $3.4 \mathrm{~m}$ in diametre) containing leaf impressions (Glossopteris) are found within this shale. The upper part of this shale succession records rich concentration of Vertebraria.

The thick accumulation of carbonaceous shale indicates slow suspension fall out under quiet, anoxic condition. The presence of Vertebraria indicates deposition under continental condition and a deep lacustrine setting can be inferred. Preservation of flattened, whole leaves of Glossopteris within carbonate concretions also suggests quiet water deposition (Picard and High 1972). The carbonate concretions are unique to the Jamunia Shale.

\subsection{Mahuda Ridge Sandstone}

The sandstone succession overlying the Hariharpur Shale was described by Fox (1930) as the Mahuda Ridge Sandstone. This sandstone succession is exposed along two prominent east-west trending parallel ridges lying to the north and south of the elliptic exposure of the Raniganj Formation (figure 2).

The Mahuda Ridge Sandstone is about $50 \mathrm{~m}$ thick, and comprises coarse-grained sandstone with trough cross-bedding $\left(\mathrm{Sd}_{\mathrm{TCB}}\right)$ and medium to coarse-grained planar cross-bedded sandstone $\left(\mathrm{Sd}_{\mathrm{PCB}}\right)$ as the major constituents. The former variety dominates over the latter. Silty shale $\left(\mathrm{Sh}_{\mathrm{GREY}}\right)$ occurs as a very minor constituent. The cross-sets are about 20 to $30 \mathrm{~cm}$ thick and form about 1.5 to $2 \mathrm{~m}$ thick cosets bounded by approximately planar to concave-up surfaces.

The disposition of two major facies of the Mahuda Ridge Sandstone resembles a broad channel complex formed by lateral channel migration or switching with moderate contemporaneous subsidence (Miall 1985). The nature of the channel stacks and minor proportion of flood plain fines suggest a braided-channel depositional environment (Rust and Gibling 1990).

\section{Paleocurrent pattern}

Cross-bedding, both trough and planar, has been primarily used for acquisition of paleocurrent data. Precise methods (Dasgupta 1995, 2002b) have been adopted for utilisation of all available sections for the purpose. The overall paleocurrent pattern indicates a dominance of northward flow during the major part of the Barren Measures sedimentation (figure 1D). The trough cross-sets encountered in the upper part of the Shibabudih Shale indicate a mean paleoflow direction towards the northeast $\left(33^{\circ}\right)$ (sector 1, figure $\left.1 \mathrm{D}\right)$. This trend correlates well with the mean paleoflow direction $\left(44^{\circ}\right)$ of the lower part of the Petia Sandstone (sector 2, figure 1D). A change in paleoflow direction towards north-northwest is observed in the upper part of the Petia Sandstone (mean flow direction $332^{\circ}$ ) (sector 3 , figure 1D). It was further shifted towards northwest during the deposition of the Tetengabad Shale (mean flow direction $304^{\circ}$ ) (sector 4, figure 1D). The orientation of channel axes in the overlying Katri Sandstone again shifted back towards north-northeast (mean flow direction $17^{\circ}$ ) (sector 6, figure 1D). The Jamuniatanr Sandstone (mean flow directions $7^{\circ}$, sector 5 , and $344^{\circ}$, sector 9, figure 1D) and Mahuda Ridge Sandstone (mean flow directions $12^{\circ}$, sector 7 , and $351^{\circ}$, sector 8 , figure 1D) record a northward paleoflow direction. Hence, in five sectors the mean paleoflow direction is towards north-northeast, in three sectors it is towards north-northwest and only in one sector (sector 4) it is towards northwest. This consistency in the paleocurrent pattern suggests that a persistent northward paleoslope was maintained during Barren Measures sedimentation.

\section{Sedimentation and tectonics}

The broad character of the Barren Measures succession under study is defined by a succession of alternating shale- and sandstone-dominated units. The shale-dominated units, in turn, are characterised by cyclic repetition of sandstone and shale, the latter being the major constituent. The cyclic variations in the rate of coarse clastic input can be attributed mainly to the sedimentary response to basin tectonics. Blair and Bilodeau (1988) suggested that in a tectonic cyclothem commencement of fine-grained sedimentation above coarse-grained deposits is the best indicator of renewed tectonic 
activity. On the basis of observations in modern settings, they attributed this model to the disparity between the rates of tectonic uplift and erosion, and the rate of response of different depositional environments to tectonic reactivation. The most compelling point in favour of this model, however, is provided by changes in tectonic geomorphology during reactivation of basin-bounding faults in a rift basin. In a half-graben tectonic model, very commonly developed in continental rift basins, the upward motion of the footwall block extends up to the fulcrum (figure 1, Leeder and Gawthorpe 1987) developing an outward regional slope of the footwall block away from the fault scarp. During fault motion, instantaneous unloading along the fault plane causes isostatic upwarp of the footwall block (Savage and Hastie 1966; Bott 1976). Jackson and McKenzie (1983) estimated this footwall uplift to be about $10 \%$ of the hangingwall subsidence. The changed physiography restrains supply of sediments derived from the footwall on the steeply dipping fault scarp. Fresh supply from the footwall block sets in only after the weathering and erosion (at least partly) of this positive topography, and deposition of coarser clastics would be resumed during tectonic quiescence. Repeated tectonic rejuvenation along the fault planes in quick succession may inhibit derivation of the coarser clastics from the footwall block as well as formation of cyclothems along the toe-zone of the fault scarp.

Sedimentation on the hangingwall dip-slope responds to the tectonic rejuvenation in a different manner. The gradient of the hangingwall dip-slope is enhanced during the tectonic events, and the existing fluvial system progrades towards the halfgraben trough depositing coarser clastics on the finer deposits of the trough. During this basin subsidence, deepening of the basin along the base of the fault causes instantaneous lacustrine transgression on the footwall block and regression on the hangingwall block (Leeder and Gawthorpe 1987). The prograding fluvial system on the hangingwall dip-slope comes above the shallow lacustrine sediments and deposits coarser clastics. With continuous fluvial sedimentation, peneplanation of the hangingwall slope and diminishing supply of coarser clastics, slow increase in the lake level causes lacustrine transgression and retrogration of the fluvial system on the hangingwall block. The coarse-grained fluvial deposits are onlapped by finer grained lacustrine sediments generating a cyclothem. Figure 13 illustrates the stages of development of tectonic cyclothem on the hangingwall block.

The sandstone-shale alternations of the Barren Measures succession can be correlated with the tectonic cyclothems developed on the hangingwall dip-slope and the adjoining trough. The footwallderived fans are, however, conspicuously absent, indicating that the basin was much more extensive than the present limit of the Barren Measures exposure. The faults presently defining the contacts between the rocks of the Barren Measures Formation and the Barakar Formation possibly came into existence after Barren Measures sedimentation.

The lower part of the Shibabudih Shale indicates deposition broadly under deep-water condition within an isolated sub-basin with periodic influx of sediment-laden flows. The wave-rippled sandstones indicate occasional prevalence of shallowwater condition. The shift from shallow-water to deep-water condition did not have any signature of penecontemporaneous deformation within the argillaceous sandstone, and a slow rate of aseismic subsidence is inferred. During the deposition of the upper part of the Shibabudih Shale the sub-basin merged with the main basin. The advancing fluvial system during the deposition of the overlying Petia Sandstone points to a major event of lacustrine regression. Lateral shifting of the successive channels and swing in paleocurrent directions towards west indicate gradual westward tilting of the basin floor. Intermittent events of tectonic reactivation are suggested by the development of large fluid escape structures within sandstone. The Petia Sandstone broadly represents the fluvial succession developed on the hangingwall dip-slope. The Tetengabad Shale also bears the character of a tectonic cyclothem. Periodic advancement of fluvial condition can be attributed to the onset of tectonic subsidence. The sandstone units are devoid of any signature of penecontemporaneous deformation though, slump structures within silty shale underlying the cross-bedded sandstone bears the signature of instability. The Katri Sandstone represents a sublacustrine fan deposit within the lacustrine setting caused by an intrabasinal normal fault in the hangingwall block. The Hariharpur Shale and the Jamunia Shale do not record any intermediate phases of fluvial influx and were possibly deposited during uninterrupted phases of tectonic quiescence. The Barren Measures sedimentation ended with the advancement of fluvial condition, which is evident from the Mahuda Ridge Sandstone in the western part of the basin.

The preceding discussion reveals that the Barren Measures sedimentation was initiated in the eastern part of the basin and gradually proceeded towards west. Hence, the basin floor underwent a gradual tilting towards west about an axis perpendicular to the direction of basin extension. The spatial distribution of the Barren Measures facies indicates that the geographic extent of different depositional settings were possibly much more 


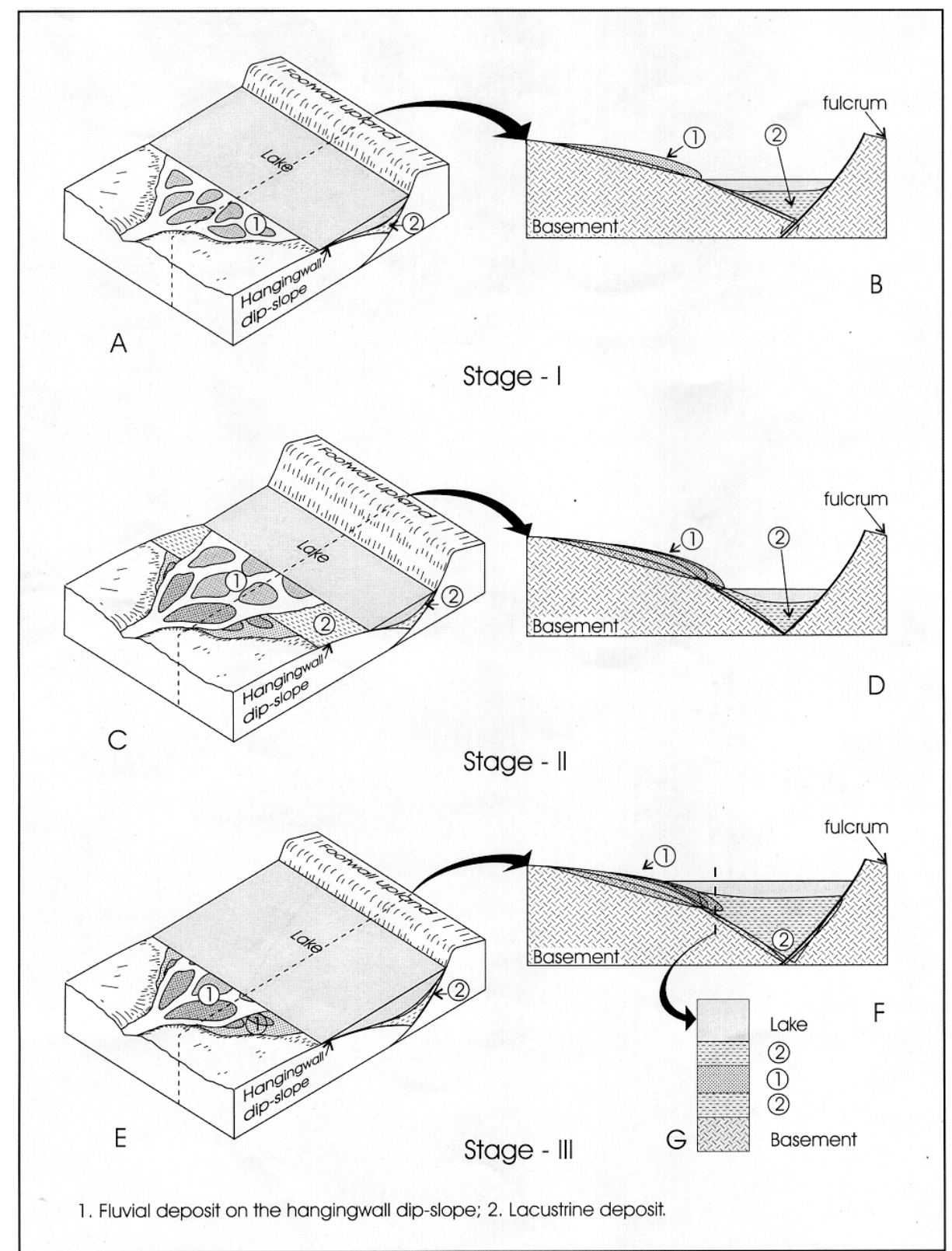

Figure 13. Schematic diagrams showing different stages of development of tectonic cyclothem on the hangingwall dip-slope in a half-graben setting. Stage-I: (A and B) The lacustrine condition developed along the axial trough of the half-graben and the fluvial system on the hangingwall dip-slope is flowing towards the axial trough. Stage-II: $(\mathbf{C}$ and $\mathbf{D})$ Subsidence due to reactivation of the fault caused fall in the lake level leading to the lacustrine regression on the hangingwall dip-slope and progradation of the fluvial system towards the axial trough, leading to deposition of fluvial sediments above the preexisting lake deposits. Stage-III: (E and F) Slow rise in the lake level and lacustrine transgression on the hangingwall dip-slope and consequent retrogradation of the fluvial system. The pre-existing fluvial deposit is buried under the lacustrine sediments.

extensive than the present outcrop limit of different units of this formation.

Ghosh and Mukhopadhyay (1985) suggested that the basin subsidence during the Barren Measures sedimentation was controlled by the Southern Boundary Fault. This proposition, however, is not supported by the conspicuous absence of coarser clastics along this regional fault and northerly paleocurrent away from the fault. The oblique truncation relation between the bedding planes and this regional fault also indicate that the fault was emplaced after the Barren Measures sedimentation.

Hence, over major parts of this sedimentation history, the basin passed through phases of tectonic quiescence. Three major phases of tectonic rejuvenation are evident from the advancement of the fluvial condition indicated by the Petia Sandstone, Jamuniatanr Sandstone and Mahuda Ridge Sandstone. 


\section{Conclusions}

The Barren Measures Formation (middle Permian) of the Lower Gondwana succession of the Jharia basin developed through fluvial-lacustrine interaction in a tectonically active half-graben basin. The succession is characterised by alternate disposition of shale- and sandstone-dominated units.

The cyclic variation in sediment caliber reflects sedimentary response to episodic rejuvenation of basin margin faults. The tectonic cyclothems of different orders can be identified within the Barren Measures succession.

The cyclothems formed by alternation of coarsegrained fluvial deposits emplaced on the hangingwall dip-slope and finer grained sediments deposited in adjacent lakes in a half-graben setting. Recurrent seismic/tectonic trigerring of the basin is also indicated by soft sediment deformation structures in different stratigraphic units.

The fluvial system was marked by a remarkably persistent northerly paleocurrent and sediment dispersal attesting to a northerly paleoslope throughout Barren Measures sedimentation. The loci of deposition were delimited by an E-W trending basin margin fault system further north of the present limit of the outcrop.

The Southern Boundary Fault did not exert any control on sedimentation as suggested by the earlier workers, and developed after the deposition of the Barren Measures sediments.

\section{Acknowledgements}

The author takes this opportunity to pay his tribute to the memory of a great teacher, scientist and philosopher, the Late Prof. S K Chanda, who devoted his life for the advancement of sedimentology in India. This work has been carried out with the financial assistance from the Department of Science and Technology, Government of India under the research project no. ESS/23/007/94. The author expresses his deep sense of gratitude to Dr. B Cairncross of Rand Afrikaans University, Dr. W Maejima of Osaka City University and Prof. A K Chaudhuri of the Indian Statistical Institute for their thoughtful reviews.

\section{References}

Alexander J and Leeder M R 1987 Active tectonic control on alluvial architecture. In: Recent development in fluvial sedimentology (eds) F G Ethridge, R M Flores and M D Harvey, Spec. Publ. Soc. Econ. Paleon. Miner. 39 $243-252$.

Blair T C and Bilodeau W L 1988 Development of Tectonic cyclothems in rift, pull-apart, and foreland basins:
Sedimentary response to episodic tectonism; Geology 16 517-520.

Bott M H P 1976 Formation of sedimentary basins of graben type by extension of the continental crust; Tectonophysics 36 77-86.

Casshyap S M 1979 Paleocurrents and basin framework an example from Jharia Coalfield, Bihar (India). In: IVth International Gondwana Symposium, Volume II (Delhi: Hindustan Publ. Co.) Pp. 627-640.

Clarke T L, Lesht B, Young R A, Swift D J P and Freeland G L 1982 Sediment resuspension by surface wave action: an examination of possible mechanisms; Mar. Geol. 49 43-59.

Dasgupta P 1995 A new model of inclinometer and its application in determination of attitude of foreset planes; J. Sediment. Res. A65 562-563.

Dasgupta P 2002a Architecture and facies pattern of a sublacustrine fan, Jharia Basin, India; Sediment. Geol. 148 373-387.

Dasgupta P 2002b Determination of paleocurrent direction from oblique sections of trough cross-stratification - a precise approach; J. Sediment. Res. 72 217-219.

Dott R H and Bourgeois J 1982 Hummocky stratification: Significance of its variable bedding sequences; Geol. Soc. Am. Bull. 93 663-680.

Dott R H and Bourgeois J 1983 Hummocky stratification: Significance of its variable bedding sequences: Reply; Geol. Soc. Am. Bull. 94 1249-1251.

Duke W L 1985 Hummocky cross-stratification, tropical hurricanes, and intense winter storms; Sedimentology 32 167-194.

Duke W L 1987 Hummocky cross-stratification, tropical hurricanes, and intense winter storms: Reply; Sedimentology 34 344-359.

Fisher R V 1977 Erosion by volcanic base-surge density currents: U-shaped channels; Geol. Soc. of Am. Bull. $8 \mathbf{8}$ 1287-1297.

Fox C S 1930 The Jharia Coalfield; Mem. Geol. Sur. India 56255.

Ghosh S K and Mukhopadhyay A 1985 Tectonic history of the Jharia Basin - an intracratonic Gondwana basin of Eastern India; Quart. J. Geol. Min. Met. Soc. India $\mathbf{5 7}$ $33-58$.

Greenwood B and Sherman D J 1986 Hummocky crossstratification in the surf zone: Flow parameters and bedding genesis; Sedimentology 33 33-45.

Harms J C, Southard J B, Spearing D R and Walker R G 1975 Depositional environments as interpreted from primary sedimentary structures and stratification sequences; Soc. Econ. Paleontol. Mineral. Short Course Notes 2161.

Harrison S and Fritz W J 1982 Depositional features of March 1982 Mount St. Helens sediment flows; Nature 299 $720-722$.

Jackson J A and McKenzie D P 1983 The geometric evolution of the normal fault systems; J. Struc. Geol. 5 471-482.

Leeder M R and Gawthorpe R L 1987 Sedimentary models for extensional tilt block/half graben basins. In: Continental extensional tectonics (eds) M P Coward, J F Dewey and P L Hancock Geol. Soc. Spec. Publ. 28 $139-152$.

Martel A T and Gibling M R 1991 Wave-dominated lacustrine facies and tectonically controlled cyclicity in the Lower Carboniferous Horton Bluff Formation, Nova Scotia, Canada; Spec. Publ. Int. Assoc. Sediment. 13 223-243.

McKee E D 1957 Flume experiments on the production of stratification and cross-stratification; J. Sediment. Petrol. 27 129-134. 
Mehta D R S and Murthy B R N 1957 A revision of the geology and coal resources of the Jharia coalfield; $\mathrm{Mem}$. Geol. Sur. India 84(2) 142.

Miall A D 1985 Architectural-Element Analysis: A new method of facies analysis applied to fluvial deposits; Earth Sci. Rev. 22 261-308.

Miall A D 1996 The geology of fluvial deposits (Berlin: Springer-Verlag) p. 582.

Mukhopadhyay A 1984 Interrelationship of tectonism and sedimentation of the Jharia Coal Basin, Eastern India; J. Geol. Soc. India 25 445-455.

Myrow P M and Southard J B 1996 Tempestite deposition; J. Sediment. Res. 66 875-887.

Picard M D and High L R Jr 1972 Criteria for recognizing lacustrine rocks. In: Recognition of Ancient Sedimentary Environments (eds) J K Rigby and W K Hamblin, Spec. Publ. Soc. Econ. Paleontol. Mineral. 16 108-145.

Reineck H E and Singh I B 1972 Genesis of laminated sand and graded rhythmites in storm-sand layers of shelf mud; Sedimentology 18 123-128.

Rust B R and Gibling M R 1990 Three-dimensional antidunes as HCS mimics in a fluvial sandstone: the Pensylvanian South Bar Formation near Sydney, Nova Scotia; J. Sediment. Petrol. 60 540-548.

Savage J C and Hastie L M 1966 Surface deformation associated with dip-slip faulting; J. Geophys. Res. 71 4897-4904.

Sengupta N, Guha P K S and Mukhopadhyay A 1979 Pattern of lower Gondwana sedimentation, Jharia Basin, a model. In: IVth International Gondwana Symposium, Volume II (Delhi: Hindustan Publ. Co.) Pp. 617-625.

Smith G A 1986 Coarse-grained nonmarine volcaniclastic sediment: Terminology and depositional process; Bull. Geol. Soc. Am. 97 1-10.

Smith G A and Lowe D R 1991 Lahars: Volcanohydrologic events and deposition in the debris flowhyperconcentrated flow continuum. In: Sedimentation in volcanic settings (eds) R V Fisher and G A Smith, Spec. Publ. Soc. Econ. Paleontol. Mineral. 45 59-70.

Southard J B, Lambie J M, Federico D C, Pile H T and Weidman C R 1990 Experiments on bed configurations in fine sands under bi-directional purely oscillatory flow, and the origin of hummocky cross-stratification; J. Sediment. Petrol. 60 1-17.

Talbot M R and Kelts K 1990 Paleolimnological signatures from carbon and oxygen isotopic ratios in carbonates from organic carbon-rich lacustrine sediments. In: Lacustrine Basin Exploration - Case Studies and Modern Analogs (ed.) B J Katz Mem. Am. Assoc. Petrol. Geol. 50 99-112.

Walker R G 1984 Shelf and shallow marine sands. In: Facies Models (ed.) R G Walker, Geosci. Can. Reprint Ser. 1 141-170.

Walker R G, Duke W L and Leckie D A 1983 Hummocky stratification: Significance of its variable bedding sequences: Discussion; Geol. Soc. Am. Bull. 94 1245-1249. 